\title{
FAKTOR-FAKTOR YANG BERPENGARUH TERHADAP BUDAYA POLITIK PEMILIH DESA ADAT \\ (Studi Kasus Tentang Tipologi Pemilih Desa Kakara Dalam Pemilihan \\ Kepala Daerah Maluku Utara) \\ Frets Alfret Goraph \\ Herson Keradjaan \\ Progra Studi Ilmu Pemerintahan Fakultas Ilmu Sosial Dan Humaniora \\ Universitas Halmahera
}

\begin{abstract}
Abstrak
Pemilihan kepala daerah Maluku Utara 2013-2018 berimplikasi terhadap desain strategi marketing politik. Budaya politik pemilih desa adat di Desa Kakara berdampak pada segmentasi tipologi pemilih dalam pemilihan kepala daerah. Strategi marketing politik kandidat digunakan sebagai alat untuk mempengaruhi pemilih. Kemudian dinamika politik uang dan kampanye hitam tidak bisa dihindari oleh masyarakat desa adat ketika proses pemilihan kepala daerah. Pentingnya penelitian ini adalah bagaimana menjelaskan dan menganalisa budaya politik pemilih yang ada di desa adat desa Kakara dalam pilkada kemudian hal-hal apa saja yang dapat mempengaruhi budaya politik Tokoh Adat di desa adat.

Penelitian studi kasus ini dirancang dengan pendekatan metode penelitian kualitatif. Untuk mendapatkan data penelitian memadai metode yang digunakan yaitu teknik penentuan informan melalui key person (orang-orang kunci). Metode pengumpulan data dilakukan dengan dua cara yaitu wawancara mendalam (indepth interview) dan kajian dokumentasi.

Temuan dalam penelitian ini bahwa Pertama; memang diakui oleh beberapa Tokoh Adat bahwa dalam kontestasi pemilihan Gubernur Maluku Utara Tahun 2013, sering terjadi jual janji politik masa kampanye kepada masyarakat dengan menawarkan program kerja serta kebijakan yang akan diambil jika terpilih. Kedua, kandidat yang menggunakan Adat-Budaya sebagai mesin politik tidak terlalu berpengaruh terhadap Tokoh Adat melainkan janji politik kandidat yang telah ditepati baru kemudian dipilih, Ketiga; tidak bisa dipungkiri bahwa politik uang sering terjadi dan itu dilakukan oleh beberapa kandidat gubernur namun kurang berpengaruh terhadap Tokoh Adat melainkan sangat berpengaruh terhadap masyarakat adat. Keempat, budaya politik Tokoh Adat cenderung cukup rasional ketika diperhadapkan dengan persoalan politik uang, agama, etnis, dan adat-budaya sebagai mesin politik kandidat, guna mempengaruhi pilihan politik Tokoh-Tokoh Adat Desa Kakara, Kelima; beberapa kandidat turut membawa adat-budaya dalam arena politik dan faktor adat juga sangat mempengaruhi perilaku pemilih Masyarakat Adat di Desa Kakara pada pemilihan gubernur Maluku Utara Tahun 2013.
\end{abstract}

Kata Kunci : Budaya Politik Pemilih Desa Adat dan Tipologi Pemilih.

\section{Latar Belakang Masalah}

Sistem politik Indonesia yang terbangun telah berimplikasi terhadap terlaksananya pemiliham umum baik ditingkat pusat sampai daerah dan desa. Di era demokrasi[1] semakin terbuka agar partisipasi masyarakat dalam memilih dan menentukan pemimpinan mereka melalui mekanisme musyawarah dan mufakat. 
Pemilihan umum kepala daerah yang terjadi turut mempengaruhi perilaku politik serta budaya politik seseorang. Artinya budaya politik pemilih menentukan tindakan pilihan politik sebagai barometer untuk memilih kandidat. Pilihan politik seseorang dalam pemilu untuk memilih kandidat dari partai politik maupun dari kandidat perseorang, tergantung branding politik serta program politik yang ditawarkan kepada pemilih guna mempengaruhi masyarakat.

Pelaksanaan pemilihan kepala daerah Maluku Utara menjadi menarik ketika berbagai kandidat mencoba memainkan isu-isu adat/budaya, agama, politik dan ekonomi sebagai komoditas politik. Banyaknya desa-desa di Maluku Utara berbasis masyarakat adat/budaya yang kemudian para kandidat mencoba mendisain strategi politik guna mempengaruhi pemilih mayoritas masyarakat adat maupun masyarakat pada umumnya.

Segmentasi pemilih dapat diklasifikasi ke dalam tipologi pemilih yaitu pemilih kritis, pemilih rasional, pemilih tradisional, dan pemilih skeptis. Namun kecederungan pemilih di Maluku Utara dikategorikan sebagai jenis pemilih tradisional. Oleh karena, mayoritas masyarakat desa di provinsi Maluku Utara berbasis masyarakat adat. Tidak terkecuali politik pemilih desa adat di desa Kakara yang mengembangkan pembangunan desa adat sebagai identitas masyarakat desa. Adat-budaya dipakai sebagai cermin dalam berperilaku. Desa Kakara sebagai desa adat yang memegang adat/budaya Hibua Lamo. Adat Hibua Lamo[2] menjadi simbol dan ideologi orang Tobelo pasca eksodus dari Talaga Lina yang tertanam secara turun temurun. Mayoritas suku yang berada di desa adat Kakara yaitu suku Tobelo-Galela dan sebagian suku pendatang karena terjadi perkawinan campuran. Dikatakan sebagai desa Kakara sebagai desa tertua sehingga dijadikan sebagai desa adat. Peran Bupati Halmahera Utara terhadap pembentukan desa adat maupun masyarakat adat diberbagai daerah Maluku Utara terus terjadi melalui lembaga asosiasi Aliansi Masyarakat Adat Nusantara (AMAN), oleh karena Bupati sebagai Ketua Dewan Adat AMAN.

Dititik inilah, bagi peneliti menarik untuk diteliti mencari tahu pola serta perilaku budaya politik pemilih masyarakat desa adat Kakara ketika berhadapan dengan kandidat yang membawa identitas adat/budaya sebagai mesin politik 
dalam pemilihan umum kepala daerah Maluku Utara jika dibandingkan dengan kandidat lain yang tidak menggunakan adat-budaya sebagai mesin politik.

Maraknya politik uang yang terjadi pada pilkada semakin menarik untuk kita cermati apakah masyarakat desa adat Kakara bisa terpancing oleh kandidat yang melakukan politik uang menjelang pilkada atau tidak, ataukah masyarakat desa adat Kakara tetap melihat adat/budaya sebagai cermin dalam pilkada artinya masyarakat menolak politik uang sehingga budaya politik pemilih berarti studi perilaku politik secara kuantitatif asumsi bahwa sikap secara langsung menentukan praktek politiknya yang beradat/berbudaya baik pula. Tetapi kemudian hal ini patut kita uji kembali karena sepertinya politik uang telah menjadi patologi sosial di masyarakat kita sehingga menjadikan demokrasi kita berjalan pincang. Ataukah ada faktor lain yang mempengaruhi perilaku memilih tokoh adat dan masyarakat adat. Budaya pemilih desa adat di desa Kakara ketika diperhadapkan dengan fenomena calon gubernur yang menggunakan adat-budaya sebagai media politik maka kecenderungan perilaku masyarakat akan ikut berubah atau tidak, akan dijelaskan dan analisis dalam penelitian ini.

\section{Landasan Teori}

Studi analisis strategi perencanaan marketing politik sebelum masuk lebih jauh untuk mendeskripsikan seperti apa dan bagaimana kandidat melakukan strategi perencanaan marketing politik maka sangat penting untuk melihat model strategi politik dalam teorinya Bruce I. Newman kemudian yang pertama, penting untuk memahami gagasan Filsul peletakan dasar marketing politik yaitu Studi marketing politik oleh teorinya Bruce I. Newman (1999) Filsuf marketing politik mengatakan bahwa :

"Political marketing is the application of marketing principles and procedures in political campaigns by various individuals and organization. The procedures involved include the analysis, development, execution, and management of strategic campaign by candidates, political party, government, lobbyists and interest group that seek to drive public opinion, advance their own ideologies win election, and pass legislation and referenda in response to the needs and wants of selected people and group in a society ${ }^{l}$.

\footnotetext{
${ }^{1}$ Newman, Bruce., The Mass Marketing of Politics Democracy in An Age of Manufactured Images, (London, New Delhi : Sage Publications, 1999), H. xiii
} 
Berdasarkan argumentasi Bruce L. Newman maka, dapat kita analisis secara kritis bahwa dalam sebuah pertarungan politik pada pemilihan umum, yang dibutuhkan adalah bagaimana kandidat calon membuat sebuah kerangka manajemen strategi politik yang kemudian dijadikan sebagai mesin politik oleh kandidat guna mempengaruhi pemilih. Kemudian diperkuat dengan pandangan Philip Kotler mengatakan bahwa, marketing politik tidak dapat memberikan jaminan kemenangan, namun dapat memastikan bahwa kampanye politik dapat dilakukan secara sistematis, efisien dan voter oriented.

Perencanaan berarti juga mengaitkan antara satu aktivitas dengan aktivitas lain. Seperti halnya menerut Kotler dan Levy (1969) memperkenalkan konsep pemasaran politik dan penggunaan alat pemasaran dalam analisis pemilihan kampanye. Pada tahun 1975, Kotler mengembangkan, pertukaran teori dalam politik; menurut teori ini, partai politik dan kandidat adanya pertukaran janji untuk mendapatkan suara dan melalui sebuah proses komunikasi dengan pemilih dan mencari informasi dari mereka untuk digunakan dalam strategi politik mereka. Dengan cara ini, political marketing menyerupai pemasaran barang ekonomi (Kotler, tahun 1975) ${ }^{2}$.

Kajian-kajian marketing politik bermunculan seperti Nursal (2004) yang membahas dasar-dasar teori tentang marketing politik. Dalam nada yang bersamaan Firmanzah (2004) juga memberikan ulasan tentang peranan ilmu marketing dalam dunia politik. Sementara Firmanzah (2005) mengupas tentang karakteristik pemilih. Terdapat beberapa jenis karakteristik pemilih, di mana masing-masing jenis membutuhkan pendekatan yang berbeda-beda. Namum seperti yang diungkapkan di atas, masih sangat dibutuhkan kajian-kajian yang membahas marketing politik, terutama dalam konteks di Indonesia ${ }^{3}$.

Marketing politik harus dilihat secara komprehensif (Lees-Marshmant, 2001) $)^{4}$. Pertama, marketing politik lebih daripada sekedar komunikasi politik. Kedua, marketing politik diaplikasikan dalam seluruh proses organisasi partai

\footnotetext{
${ }^{2}$ Apospori Eleni, Avlonitis George and Zisouli Maria..(2010).'Political Culture and Perception of political Marketing Tools: A Cross Generational Comparison', Journal of Political Marketing. p. 115

${ }^{3}$ Firmanzah. 2012. Marketing Politik ; Antara Pemahaman Dan Realitas. Penerbit; Yayasan Pustaka Obor Indonesia. Jakarta. Hal. XXXVIII-XLI

${ }^{4}$ Firmanzah. 2012. Marketing Politik ; Antara Pemahaman Dan Realitas. Penerbit; Yayasan Pustaka Obor Indonesia. Jakarta. Hal. 198
} 
politik. Tidak hanya tentang kampanye politik tetapi sampai juga pada tahap bagaimana memformulasikan produk politik melalui pembangunan simbol, image, platform dan program yang ditawarkan. Ketiga, marketing politik menggunakan konsep marketing secara luas, tidak hanya tidak terbatas pada teknik marketing, namum juga sampai strategi marketing, dari teknik publikasi, menawarkan ide dan program serta desain produk sampai ke market intelligent dan pemprosesan informasi. Keempat, marketing politik melibatkan banyak disiplin ilmu dalam pembahasannya, seperti sosiologi, psikologi, misalnya produk politik merupakan fungsi dari pemahaman sosiologi mengenai simbol dan identitas, sedangkan faktor psikologinya adalah kedekatan emosional dan karakter seseorang pemimpin, sampai ke aspek rasionalitas platform partai. Kelima, konsep marketing politik bias diterapkan dalam berbagai situasi politik, mulai dari pemilihan umum sampai ke proses lobi di parlemen.

\section{Tipologi Pemilih}

Adapun kriteria dari pemilih, yaitu terdiri atas empat (4) kriteria antara lain:

\section{Pemilih Rasional}

Pemilih memiliki orientasi tinggi pada policy-problem-solving dan berorientasi rendah untuk faktor ideologi. Pemilih dalam hal ini lebih mengutamakan kemampuan partai politik atau calon kontestan dalam program kerjanya. Program kerja atau platform partai bisa dianalisis dalam dua hal : 1) Kinerja partai di masa lampau, 2) tawaran program untuk menyelesaikan permasalahan nasional yang ada. Kinerja partai atau kontestan biasanya termanifestasikan pada reputasi dan citra (image) yang berkembang di masyarakat. Pemilih jenis ini menggunakan analisis kognitif dan pertimbangan logis yang sangat dominan dalam proses pengambilan keputusan.

\section{Pemilih Kritis}

Pemilih jenis ini merupakan perpaduan antara tingginya orientasi pada kemampuan partai politik atau seseorang kontestan dalam menuntaskan permasalahan bangsa maupun tingginya orientasi mereka akan hal-hal yang bersifat ideologis. Pentingnya ikatan ideologis membuat loyalitas pemilih terhadap sebuah partai atau kontestan cukup tinggi dan tidak semudah rational voter untuk berpaling ke partai lain. Tiga kemungkinan yang akan muncul ketika 
terdapat perbedaan antara nilai ideologi dengan platform partai : 1) memberikan kritik internal, 2) frustasi, 3) membuat partai baru yang memiliki kemiripan karakteristik ideologi dengan partai lama. Pemilih jenis ini harus di manage sebaik mungkin oleh sebuah partai politik atau seeorang kontestan.

\section{Pemilih Tradisional}

Pemilih dalam jenis ini memiliki orientasi ideologi yang sangat tinggi dan tidak terlalu melihat kebijakan partai politik atau kontestan sebagai sesuatu yang penting dalam pengambilan keputusan. Pemilih tradisional sangat mengutamakan kedekatan sosial-budaya, nilai, asal usul, paham, dan agama sebagai ukuran untuk memilih sebuah partai politik. Kebijakan partai dianggap sebagai parameter kedua. Mereka tidak terlalu memusingkan diri pada kebijakan apa yang telah dilakukan dan apa yang akan dilakukan partai politik yang mereka dukung. Biasanya pemilih jenis ini lebih mengutamakan figur dan kepribadian pemimpin, mitos dan nilai historis sebuah partai politik atau seorang kontestan. Salah satu karakteristik mendasar jenis pemilih ini adalah tingkat pendidikan yang rendah dan sangat konservatif dalam memegang nilai serta paham yang dianut.

\section{Pemilih Skeptis}

Tidak memiliki orientasi ideologi yang cukup tinggi dengan sebuah partai politik atau kontestan, juga tidak menjadi kebijakan sebagai sesuatu yang penting. Keinginan untuk terlibat dalam sebuah partai politik pada pemilih jenis ini sangat kurang, karena ikatan ideologis mereka memang rendah sekali. Mereka juga kurang memedulikan platform dan kebijakan sebuah partai politik. Golongan putih sangat didominasi jenis pemilih ini. Kalaupun berpartisipasi dalam pemungutan suara, biasanya mereka melakukannya secara acak atau random. Mereka berkeyakinan bahwa siapapun dan partai apapun yang memenangkan pemilu tidak akan bisa membawa bangsa ke arah perbaikan yang mereka harapkan.

\section{METODE PENELITIAN}

\section{Jenis Penelitian}

Desain penelitian ini dirancang dengan pendekatan metode kualitatif. Analisis kualitatif dalam penelitian ini bertujuan untuk menelusuri dengan menggambarkan, menjelaskan serta menganalisi bagaimana budaya politik 
pemilih desa adat di desa Kakara dalam pilkada Maluku Utara. Inilah kemudian kenapa peneliti mengunakan metode penelitian kualitatif.

\section{Metode Penentuan Informan Penelitian}

Dalam studi ini penulis menentukan informan melalui key persons, karena awalnya penulis sudah mengetahui informasi awal tentang objek maupun informan penelitian. Key persons (orang-orang kunci) tersebut antara lain adalah tokoh-tokoh yang terlibat secara langsung atau yang mengamati ${ }^{5}$. Key person (orang-orang kunci) yang dimaksud untuk mendapatkan informasi adalah seperti ; seluruh tokoh adat di desa Kakara.

\section{Metode Pengumpulan Data}

Dari berbagai metode pengumpulan data yang ada, studi ini menggunakan metode yang bersandar pada wawancara mendalam dan dokumen tertulis. Penulis memilih metode tersebut untuk bisa saling melengkapi.

1. Wawancara mendalam yaitu wawancara yang memerlukan pertanyaanpertanyaan yang lebih terstruktur dengan teknik wawancara mendalam (indepht interview). Hal ini dimaksudkan agar peneliti dapat menggali informasi lebih luas dari informan penelitian seperti yang disebutkan di atas, oleh karenanya selain menanyakan fakta-fakta sosio-politik terkait dengan peristiwa yang diteliti, maka peneliti juga bisa meminta opini tentang fenomena politik lain yang terjadi dan dialami oleh informan tersebut.

2. Kajian Dokumentasi. Dokumentasi dalam hal ini adalah suatu upaya untuk memperoleh data-data sekunder yang diperlukan dalam penelitian ini.

\section{Teknik Analisis Data}

Salah satu strategi yang paling umum dalam analisis data kualitatif adalah menggunakan strategi analisis naratif. Analisis naratif mengacu pada jenis data kualitatif, bentuk penyelidikan dan pengumpulan data, cara untuk membahas dan menyajikan data, seperangkat teknik analisis data kualitatif, dan semacam penjelasan teoritis. Sebagaimana diamati oleh Griffin (1992a:419), "Naratif

\footnotetext{
${ }^{5}$ Bungin, ibid., hal. 77
} 
adalah bentuk retorika dan bentuk umum yang logis dari penjelasan yang menggabungkan deskripsi berteori dari suatu peristiwa dengan penjelasannya ${ }^{6}$.

\section{PEMBAHASAN}

\section{Faktor Yang Berpengaruh Terhadap Budaya Politik Tokoh Adat Desa Kakara}

Mencermati keunggulan utama dari konsep budaya politik adalah untuk menunjukkan bahwa perilaku politik harus dilihat dalam konteks budaya. Perilaku politik ini disutradarai oleh interpretasi dan preferensi, bukan oleh fakta-fakta yang memperlihatkan kepentingan dan kekuasaan. Gagasan tentang budaya menekankan pentingnya makna, interpretasi, pembenaran, wacana dan lebih umumnya faktor kognitif dan afektif yang menjadi dasar tidak terjadinya minimalisme budaya politik. Menurut Duffield (1999) istilah budaya politik telah digunakan untuk menandakan orientasi subjektif ke arah dan asumsi tentang dunia politik yang mencirikan anggota masyarakat tertentu dan panduan untuk menginformasikan perilaku politik mereka. Ada tiga komponen dasar budaya politik seseorang yaitu, pertama; Kognitif, yang mencakup empiris dan sebabakibat keyakinan. Kedua; Evaluatif, yang terdiri dari nilai-nilai, norma, dan penilaian moral. Ketiga; Ekspresif atau afektif, yang meliputi emosional cinta, pola identitas dan loyalitas, dan perasaan daya tarik, keengganan atau ketidakpedulian.

Dari ketiga komponen dasar budaya politik di atas dapat kita artikan bahwa semakin tinggi kesadaran budaya politik, maka meningkatnya pula tingkat pendidikan dan keterampilan kognitif, evaluative dan afektif sebagai dasar perilaku politik seseorang. Dalam akses keterampilan ini akan memberikan berbagai sumber informasi politik yang dapat disaring dengan baik misalkan informasi politik melalui media massa dianggap memainkan peran penting dalam mengubah dasar perilaku pemilih yang telah mewakili pergeseran dari politik loyalitas terhadap politik pilihan. Selain itu, karena penyebab pada dasarnya dalam masyarakat terjadi perubahan dalam tingkat pendidikan, akses ke media massa, dan penurunan organisasi politik tradisional secara luas dianggap

\footnotetext{
${ }^{6}$ Neuman Lawrence W. 2013. Metodologi Penelitian Sosial : Pendekatan Kualitatif Dan Kuantitatif. Edisi 7. PT. Indeks. Jakarta. Hal. 578
} 
mempengaruhi semua masyarakat yang sama. Tetapi yang menjadi masalah adalah akses masyarakat tradisional terhadap informasi politik dengan rendahnya tingkat pendidikan, maka ini yang menjadi fenomena ironi politik mereka, menerima pseudo informasi politik media yang tidak fair dalam pemberitaan informasi dan pemasaran politik setiap kandidat lain.

Dalam konteks pasca pemilihan Gubernur Maluku Utara Tahun 2013, juga turut mempengaruhi budaya politik tokoh adat dan masyarakat adat di Desa Kakara. Strategi pemasaran politik kandidat menentukan sikap dan perilaku tokoh adat yang ada di Desa Kakara. Berbagai strategi pemasaran politik kandidat digunakan berupa slogan kandidat "COBLOS BAJU ADAT", dan PUTRA CANGA, serta anak daerah dijadikan sebagai mesin pemasaran politik kandidat guna mempengaruhi tokoh adat dan memperoleh suara terbanyak pada pemilihan umum. Telah dijelaskan pada hasil wawancara di atas bahwa, factor dominan yang berpengaruh terhadap budaya politik tokoh adat yaitu berhubungan dengan tingkat pengetahuan (kognisi) tokoh adat terhadap setiap kandidat baik itu gaya hidup, dan latar belakang semasa dia hidup dan program politik macam mana yang dipasarkan. Namun hasil penelitian ini menunjukan bahwa factor dominan yang berpengaruh yaitu "Figur atau Ketokohan seorang kandidat" dalam mempertahankan dan memperjuangkan adat-budaya yang sedang terkikis oleh arus globalisasi.

Pengaruh Ketokohan seorang kandidat yang pertama yaitu Ir. Hein Namotemo, Sahril S.H., dan Hj. Gani Kasuba, mantan wakil Gubernur sebelum pilkada Gubernur Tahun 2013. Ketiga Tokoh inilah yang turut mempengaruhi budaya politik tokoh adat yang ada di Desa Kakara. Hal itu terbukti ketika pada PILGUB putaran pertama yang memperoleh suara terbanyak dan rata-rata seluruh tokoh adat memilih $\mathrm{Hj}$. Gaji Kasuba. Mengapa karena pak $\mathrm{Hj}$. Gani sudah memberikan bantuan berupa "GENSET $5 \mathrm{Kg}$ " kepada masyarakat desa Kakara sebagai listrik desa mengingat PLN belum masuk Desa Kakara. Selain itu pak Hj. Gani, merupakan putra Tobelo-Galela sebagai representasi orang Tobelo-Galela yang ada di Desa Kakara. Hal tersebutlah yang membuat Seluruh Tokoh adat turut memilih dan memenangkan Pak Hj. Gani sebagai Gubernur Maluku Utara. Penelitian ini tidak mengungkap proses hukum yang terjadi yang mana pak Hein 
dan Gani menggugat hasil pleno KPU Maluku Utara yang memenangkan Ahmad Hidayat Mus sebagai Gubernur terpilih versi KPU. Pasca gugatan di Mahkamah Konstitusi kemudian pada putaran kedua diikuti hanya kedua pasangan calon gubernur yaitu $\mathrm{Hj}$. Gani Kasuba dan AHM.

Kemudian putaran ke dua ini sangat panas sausana perpolitikan di Maluku Utara. Karena sakit hati pak Hein terhadap AHM sehingga pak Hein dengan tegas mendorong para pendukung dan simpatisannya untuk memilih pak $\mathrm{Hj}$. Gani Kasuba pada putaran kedua PILGUB. Mengingat pak Gani merupakan putra Tobelo-Galela dan tentu persoalan politik yang selalu berubah mengikuti arah mata uang. Namun secara tegas seluruh tokoh adat yang ada di Desa Kakara memilih pak $\mathrm{Hj}$. Gani Kasuba, mengingat jasa-jasa dan bukti yang telah ditunjukan kepada masyarakat desa Kakara.

\section{Pengaruh Politik Uang Bagi Masyarakat Adat dan Tokoh Adat}

Seperti permasalahan pemilu sebelumnya, isu-isu politik uang mungkin akan menjadi salah satu persoalan pemilih tradisional. Mereka ini umumnya dengan mudah dibohongi politisi yang melakukan politik uang. Para pemilih disadarkan bahwa politik uang hanya menciptakan pemenang yang akan tersandera karena semua dana yang digunakan untuk menyogok pemilih harus kembali. Pemilih perlu mendapatkan pemahaman atau pendidikan politik semacam ini baik melalui kegiatan lembaga swadaya masyarakat maupun aktivis politik menginginkan terciptanya pemimpin yang berintegritas. Para stakeholder yang sedang melakukan praktik kerja lapangan di desa-desa agaknya perlu menjelaskan pentingnya pendidikan politik kepada masyarakat desa bahwa politik uang pada akhirnya melahirkan politisi korup.

Beberapa contoh menghadapi pilkada DKI misalkan pernyataan dari Ketua Bawaslu Muhammad "menilai politik uang termasuk kejahatan politik. Ia berkomitmen, pada pilkada mendatang, pihaknya akan mengusut dugaan politik uang. Muhammad mengajak para pengawas pemilu bekerja profesional dengan tidak memandang perbedaan terhadap salah satu pasangan calon. Ia juga mengajak masyarakat peduli terhadap dugaan pasangan calon yang melakukan 
praktek politik uang. Langkah Bawaslu tidak bisa berjalan sendiri". ${ }^{7}$ Kasus money politik yang terjadi di Kabupaten Halmahera Timur yaitu "Penetapan Rudi dan Muhdin sebagai tersangka dilakukan setelah penyidik menemukan empat alat bukti. Sengaja peneliti mengambil contoh kasus Money Politic yang terjadi pada pemilu. Memang diakui oleh tokoh-tokoh adat Desa Kakara bahwa pernah terjadi money politic pada pilgub Maluku Utara yang diduga dilakukan oleh kandidat AHM bersama tim suksesnya ketika turun kampanye dan pada pelaksanaan pemilihan gubernur. Berdasarkan hasil wawancara di atas prinsipnya sebagai tokoh adat menentang keras calon gubernur melakukan politik uang dan dengan tegas mereka (tokoh adat) tidak memilih kandidat yang melakukan politik uang. Tokoh adat pun melakukan sosialisasi dan pencerahan kepada masyarakat adat di Desa Kakara bahwa calon gubernur yang melakukan politik uang hendaknya masyarakat jangan memilih calon tersebut, mengapa karena setelah calon tersebut terpilih menjadi gubernur maka ia akan korupsi.

\section{Respon Tokoh Adat Terhadap Simbolisasi Adat-Budaya Sebagai Media Politik Kandidat}

Di dalam perang simbolik tersebut, kekuatan dan bagaimana kekuatan tersebut digunakan akan menentukan siapa yang memeroleh hegemoni. Bila kekuatan sangat dominan dalam perang hegemoni tersebut, dalam pengertian bahwa kekuatan (senjata politik massa) digunakan dalam memaksakan sebuah hegemoni, maka prinsip hegemoni menemukan sebentuk pendalam perang hegemoni tersebut, dalam pengertian bahwa kekuatan (senjata politik massa) digunakan dalam memaksakan sebuah hegemoni, maka prinsip hegemoni menemukan sebentuk penyimpangannya dari bingkai masyarakat sipil sebagai mana dikatakan Gramsci, yang di dalamnya berlangsungan berbagai bentuk pemaksaan, represi, dan kekerasan. Salah satu kekerasan yang mungkin berlangsung di dalam media adalah apa yang disebut kekerasan simbol. Salah satu calon gubernur Maluku Utara yang menggunakan adat-budaya sebagai mesin politik kandidat lihat gambar dibawah ini:

7 Tempo.co, Jakarta: Wakil Ketua Komisi II Dewan Perwakilan Rakyat (DPR) Ahmad Riza Patria mendorong Badan Pengawas Pemilu (Bawaslu) mengungkap praktek politik uang pada pemilihan kepala daerah. Ia meyakini politik uang itu ada tapi sulit dideteksi. "Saya harap ada yang tertangkap sebagai efek jera,". Diakses: DPR Dorong Bawaslu Ungkap Pelaku Politik Uang Di Pilkada. Selasa, 25 Oktober 2016 | 19:30 WIT. 
Gambar 1.

Calon Independen Gubernur Maluku Utara Menggunakan Simbol Adat

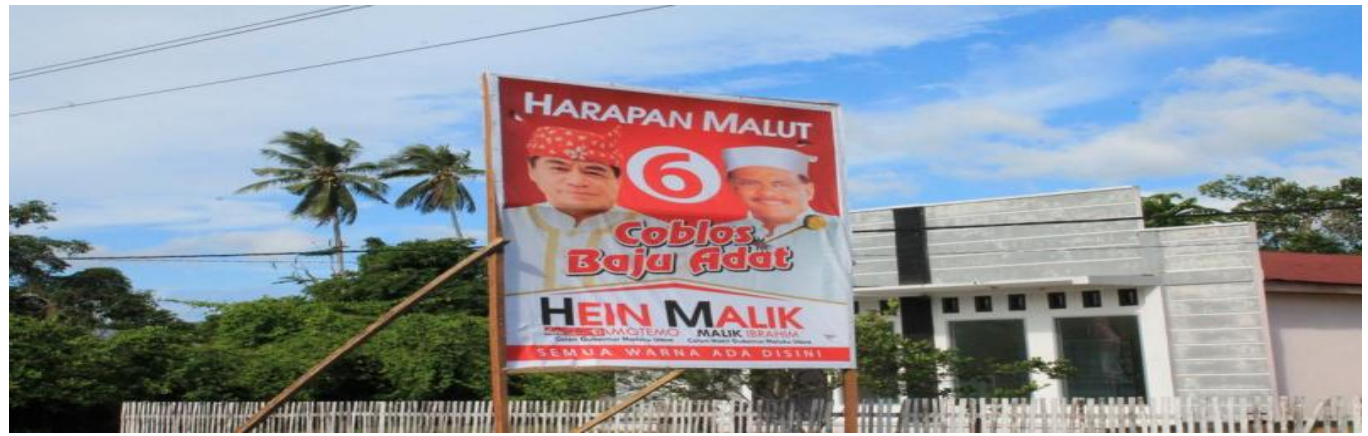

Berdasarkan hasil wawancara di atas seluruh tokoh adat Desa Kakara secara tegas menolak adat-budaya orang Maluku Utara terlebih khusus adatbudaya Tobelo Galela digunakan sebagai mesin politik kandidat. Salah satu hal membuat tokoh adat tidak memilih calon gubernur tersebut ditambah lagi pak Hein tidak lagi menepati janji politiknya kepada tokoh adat dan masyarakat Desa Kakara ketika masih menjabat sebagai Bupati Halmahera Utara pada periode kedua. Itu artinya sikap politik tokoh adat jelas dengan tidak memilih calon Gubernur tersebut karena adat-budaya Tobelo-Galela dipolitisasi. Pak Hein sebagai calon Gubernur independen adalah mantan Bupati Kabupaten Halmahera Utara, juga seorang pengagas adat-budaya Tobelo-Galela di Halmahera Utara, sebagai Jiko Makolano (Raja), dan sebagai Ketua Dewan Adat Nusantara Indonesia ketika itu mencalonkan diri sebagai calon Gubernur Maluku Utara.

Sebagai Tokoh Adat Desa Kakara jika dianalisis lebih dalam dari seluruh hasil wawancara di atas maka dapat dijelaskan sikap politik tokoh adat dalam memilih calon Gubernur Maluku Utara yang menggunakan adat-budaya TobeloGalela sebagai mesin politik kandidat sebagai berikut; a) tokoh adat Desa Kakara pada dasarnya memilih calon gubernur melihat pada apa yang sudah diberikan kepada masyarakat desa Kakara itu artinya kepentingan public (kepentingan masyarakat desa Kakara lebih penting daripada kepentingan tokoh adat), b) symbol adat-budaya tidak berpengaruh, dan agama bukan menjadi penentu tokoh adat memilih calon Gubernur. Kemudian dari beberapa indicator tersebut di atas maka sikap politik Tokoh Adat Desa Kakara sebagai Pemilih Tradisional namun keputusan politik bersifat Rasional. Rasional ketika menolak politik uang, adatbudaya dipolitisasi, dan mengutamakan kepentingan masyarakat Desa Kakara 
diatas kepentingan Tokoh Adat. Sikap politik tersebut lantas membentuk tipe pemilih tradisional menjadi pemilih rasional dan kritis namun perlu diuji kembali pada penelitian lanjutan.

\section{Simpulan}

Bertolak dari rumusan masalah dan pertanyaan penelitian dengan tokohtokoh adat Desa Kakara dengan melihat pada permasalahan penelitian ini yaitu Faktor-Faktor Yang Berpengaruh Terhadap Budaya Politik Pemilih Desa Adat (Studi Kasus Tentang Tipologi Pemilih Desa Kakara Dalam Pemilihan Kepala Daerah Maluku Utara), maka dapat tarik beberapa kesimpulan pada penelitian ini antara lain, Pertama; memang diakui oleh beberapa Tokoh Adat bahwa dalam kontestasi pemilihan Gubernur Maluku Utara Tahun 2013, sering terjadi jual janji politik masa kampanye kepada masyarakat dengan menawarkan program kerja serta kebijakan yang akan diambil jika terpilih. Kedua; kandidat yang menggunakan Adat-Budaya sebagai mesin politik tidak terlalu berpengaruh terhadap Tokoh Adat melainkan janji politik kandidat yang telah ditepati baru kemudian dipilih, Ketiga; tidak bisa dipungkiri bahwa politik uang sering terjadi dan itu dilakukan oleh beberapa kandidat gubernur namun kurang berpengaruh terhadap Tokoh Adat melainkan sangat berpengaruh terhadap masyarakat adat. Keempat; budaya politik Tokoh Adat cenderung cukup rasional ketika diperhadapkan dengan persoalan politik uang, agama, etnis, dan adat-budaya sebagai mesin politik kandidat, guna mempengaruhi pilihan politik Tokoh-Tokoh Adat Desa Kakara, Kelima; beberapa kandidat turut membawa adat-budaya dalam arena politik dan factor adat juga sangat mempengaruhi perilaku pemilih Masyarakat Adat di Desa Kakara pada pemilihan gubernur Maluku Utara Tahun 2013.

\section{Saran}

Diperlukan pendidikan politik warga Negara pada setiap sektor usia dan wilayah yang harus dilakukan oleh Kesbangpol, Partai politik[3], Perguruan Tinggi, dan Civil society yang berkelanjutan dalam membangun moral dan peradaban bangsa.

\section{Daftar Pustaka}

Abdulallah, Irwan. 2010. Konstruksi dan Reproduksi Budaya. Yogyakarta: Pustaka Pelajar. 
Arif, Syaiful. 2010. Refilosofi Kebudayaan, Pergeseran Pascastruktural. Yogyakarta: AR-Ruzz Media.

Apospori Eleni, Avlonitis George, And Zisouli Maria. 2010. "Political Culture And Perception Of Political Marketing Tools: A Cross Generational Comparison: Journal Of Political Marketing. Online Publication Date;19 February 2010.

Bungin, Burhan. 2010. Penelitian Kualitatif: Komunikasi, Ekonomi, Kebijakan Publik dan Ilmu Sosial Lain. Jakarta: Kencana Perdana Media Group.

Davidson, Jamie S. At al. 2010. Adat dalam Politik Indonesia. Jakarta: Yayasan Obor Indonesia dan KITLV-Jakarta.

Duan, S S. 2010. Hein Dan Hibualamo: Tobelo Pos Menelusuri Jejak Kepemimpinannya. Tobelo: Tobelo Pos dan Pemdah Halut.

Duan, S S. 2011. O Hoya; Mengenang Kepulangan Jan Namotemo. Tobelo: Tobelo Pos dan Institut Hendrik Van Dijken.

Firmanzah. 2012. Marketing Politik ( Antara Pemahaman Dan Realitas : Edisi Revisi ). Yayasan Pustaka Obor Indonesia. Jakarta.

Firmanzah. 2010. Persaingan, legitimasi kekuasaan, dan Marketing Politik ( Pembelajaran Politik Pemilu 2009 ). Yayasan Pustaka Obor Indonesia. Jakarta.

Firmanzah. 2005. "Menyoal Rasionalitas Pemilih: Antara Orientasi Ideologi Dan "Policy-Problem-Solving”. Manajemen Usahawan Indonesia, (33)

[1] Frets A. Goraph, "Perlukah Kesetaraan Dalam Politik Anggaran?," UNIERAJurnal Ilm. Lintas Ilmu, vol. 4, no. 2, pp. 27-34, 2015.

[2] Frets A. Goraph, "Pemasaran Politik Calon Independen dalam Pemilihan Umum Kepala Daerah Maluku Utara," UNIERAJurnal Ilm. Lintas Ilmu, vol. 4, no. 1, pp. 49-55, 2015.

[3] Frets A. Goraph \& Adrian Lopak, "Mekanisme Rekrutmen Partai Politik Dalam Penetapan Calon Legislatif Di Kabupaten Halmahera Utara (Studi Kasus di DPC PDIP Kabupaten Halmahera Utara 2014)," WIDYA SARI J.

Ilm. Pendidikan, Sejarah, dan Sos. Budaya, vol. 18, no. 5, pp. 61-75, 2016.

Klinken, Gerry Van. 2007. Perang Kota Kecil; Kekerasan Komunal dan Demokratisasi di Indonesia. Jakarta: Yayasan Obor Indonesia.

Maunati, Yekti. 2004. Identitas Dayak; Komodifikasi dan Politik Kebudayaan. Yogyakarta: LKIS.

Moleong, Lexy J. 2001. Metode Penelitian Kualitatif. Bandung: PT Remaja Rosdakarya.

Newman, Bruce I (ed.), Handbook of Political Marketing, (London : Sage Publication Inc., 1999).

Neuman Lawrence W. 2013. Metodologi Penelitian Sosial : Pendekatan Kualitatif Dan Kuantitatif. Edisi 7. PT. Indeks. Jakarta.

Pemerintah Daerah Kabupaten Halmahera Utara dan Consultant ITTC. 2009. Hibua Lamo; Memahami Eksistensi Serta Mendalami Filosofi Kaum Hibua Lamo di Jazirah Halmahera. Tobelo: Pemda Halut.

Setyanto, Widya P. dan Pulungan, Halomoan. 2009. Politik Identitas: Agama, Etnisitas dan Ruang/Space dalam Dinamika Politik di Indonesia dan Asia Tenggara. Salatiga: Persemaian Cinta Kemanusiaan (Percik)

Sugiyono, 2008. Metode Penelitian Kuantitatif, Kualitatif dan $R \& D$. Bandung: Alfabeta 
Tindage, Ruddy. 2006. Damai yang Sejati; Rekonsiliasi di Tobelo, Kajian Teologi dan Komunikasi. Jakarta: YAKOMA-PGI.

Topatimasang, Roem. 2004. Orang-Orang Kalah. Yogyakarta: Insis Press.

Ubed, S, Abdilah. 2002. Politik Identitas; Pergulatan Tanda Tanpa Identitas. Magelang: Indonesiatera.

Yanuarti, Sri, dkk. 2004. Konflik Maluku Utara; Penyebab, Karakteristik dan Penyelesaian Jangka Panjang. Jakarta: LIPI. 